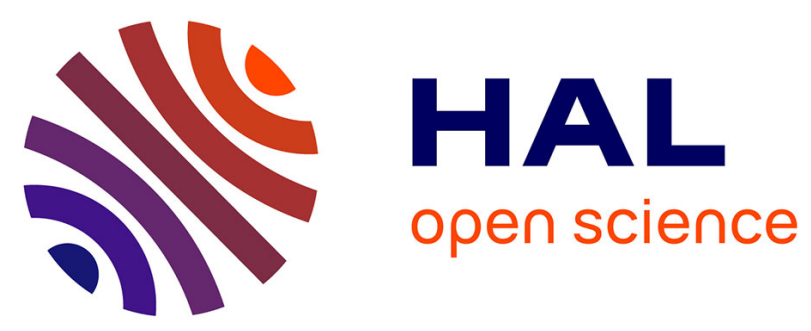

\title{
Assessing Hafting Adhesive Efficiency in the Experimental Shooting of Projectile Points: A new Device for Instrumented and Ballistic Experiments Yves Gaillard, Lorène Chesnaux, Marion Girard, Alain Burr, Evelyne Darque-Ceretti, Eric Felder, Arnaud Mazuy, Martine Regert
}

\section{To cite this version:}

Yves Gaillard, Lorène Chesnaux, Marion Girard, Alain Burr, Evelyne Darque-Ceretti, et al.. Assessing Hafting Adhesive Efficiency in the Experimental Shooting of Projectile Points: A new Device for Instrumented and Ballistic Experiments. Archaeometry, 2016, 58 (3), pp.465-483. 10.1111/arcm.12175 . hal-01174761

\section{HAL Id: hal-01174761}

https://hal-mines-paristech.archives-ouvertes.fr/hal-01174761

Submitted on 25 Nov 2019

HAL is a multi-disciplinary open access archive for the deposit and dissemination of scientific research documents, whether they are published or not. The documents may come from teaching and research institutions in France or abroad, or from public or private research centers.
L'archive ouverte pluridisciplinaire HAL, est destinée au dépôt et à la diffusion de documents scientifiques de niveau recherche, publiés ou non, émanant des établissements d'enseignement et de recherche français ou étrangers, des laboratoires publics ou privés. 


\title{
ASSESSING HAFTING ADHESIVE EFFICIENCY IN THE EXPERIMENTAL SHOOTING OF PROJECTILE POINTS: A NEW DEVICE FOR INST RUMENTED AND BALLISTIC EXPERIMENTS
}

\author{
Y. GAILLARD \\ Département de Mécanique Appliquée (Mec'appli), Institut FEMTO-ST, 24 chemin de l'épitaphe, 25000 Besançon, France
}

\section{CHESNAUX}

Université de Paris 1 and UMR 7264 CEPAM (Cultures et Environnements. Préhistoire, Antiquité, Moyen Âge) Université Nice Sophia Antipolis-CNRS. Pôle Universitaire de Saint-Jean-d'Angély 3, 24 Avenue des Diables bleus, F-06357 Nice Cedex 4, France

\section{GIRARD}

Institut de Recherche en Génie Civil et Mécanique, LUNAM Université, Université de Nantes, Ecole Centrale de Nantes, 37 Bd de l'Université, BP 406, 44602 Saint-Nazaire, France

\section{A. BURR, E. DARQUE-CERETTI and E. FELDER}

MINES ParisTech, PSL—Research University, CEMEF_Centre de mise en forme des matériaux, CNRS UMR 7635, CS 10207 rue Claude Daunesse, 06904 Sophia Antipolis Cedex, France

\section{A. MAZUY and M. REGERT $\dagger$}

Université Nice Sophia Antipolis, CNRS, CEPAM, UMR 7264, 06300 Nice, France

With the aim of providing better control of shooting experiments performed with replicas of prehistoric projectiles, we have conducted an instrumental archaeology study on the efficiency of prehistoric projectile points by placing emphasis on their adhesion and ballistic characteristics. In order to avoid any reproducibility problems, hafting adhesives were made with controlled mixtures of commercial rosin (also called 'colophany') and beeswax added as a plasticizer. An original experimental device has been developed to instrument a bow, allowing the control of both the trajectories and the velocities of the different shoots. In the course of an experimental programme on Sauveterrian microliths from the Mesolithic period of the South of France, the experimental system was applied to composite replica projectile tips of Mesolithic hunters. Arrows being shot at transparent targets were filmed in order to evaluate the penetration length and residual damage. Interestingly, this study reveals that the properties of the mixture are highly dependent on the velocity of the arrows. It was shown that-contrary to previous experiments that usually used a mixture in which rosin predominates - the most efficient adhesive is made of $70 \mathrm{wt} \%$ beeswax with only $30 \mathrm{wt} \%$ rosin. This result is of great importance for improving further shooting experiments and overcoming the problems frequently mentioned due to the loss of the flint armatures before they reach the animal target, or at least before penetration. When using this appropriate mixture, the lateral armatures are resistant to most of the 
shots. Experiments performed on real boars' flesh have also shown that the presence of lateral microliths allows the laceration inflicted on the target to be enlarged. Finally, a critical parameter has been identified, which is the location on the arrow of the microlithic element.

\section{KEYWORDS: COMPOSITE PROJECTILE TIPS, FLINT ARMATURES, ORGANIC ADHESIVE, MECHANICAL PROPERTIES, PINE RESIN, BEESWAX}

\section{INTRODUCTION}

The variability and evolution of projectile utensils during the Palaeolithic and Mesolithic periods are good indicators of the socio-economic organization of prehistoric societies (Valentin 2008; Bon 2009). Their study relies on the determination of the techno-functional characteristics of lithic and bone implements and often involves the use of replica projectiles shot at animal targets. By means of these experiments, it is possible to determine the origin of micro- and macrowears observed on prehistoric projectiles, to assess the performance of arrows and weapons, to reconstruct their hafting system, to better understand their ballistic characteristics and to monitor the damage caused to animals by the different projectiles tested (Barton and Bergman 1982; Moss and Newcomer 1982; Fischer et al. 1984; Arndt and Newcomer 1986; Geneste and Plisson 1990; Cattelain and Perpère 1993; Pokines 1998; Soriano 1998; Stodiek 2000; O'Farrell 2004; Borgia 2008; Chesnaux 2008; Letourneux and Pétillon 2008; Márquez and Muñoz 2008; Yaroshevich et al. 2010; Pétillon et al. 2011). Since the 1980s, several authors have successfully improved our understanding of hunting systems of past societies in this way. Nevertheless, these experiments still need to be improved; in particular, with better control of the ballistic parameters, including the velocity, the trajectory and deep investigation of the impact. The importance of controlling the properties of hafting glue has also been pointed out (Odell and Cowan 1986, 204). For instance, Pétillon and collaborators indicate, in the conclusion of a recent paper, that 'a firmer hafting adhesive of the bladelets on the points seems far more likely to be desirable' (Pétillon et al. 2011); this point has also been mentioned previously by other authors (Caspar and De Bie 1996, 445; Crombé et al. 2001, 260; Sisk and Shea 2009, 2042). In the course of experiments carried out by one of us (LC) to determine the process of use and the performance of Mesolithic composite tips by shooting replica projectiles at boar carcasses, we quickly observed that the glue used to fix the microliths onto the wooden shaft was a key element for the success of the experimentation. Indeed, in most cases, the lithic barbs fell off before passing through the barrier of hair and skin, which made the experiment totally ineffective (Chesnaux 2008). The loss of adhesion between lateral armatures and spears is thus clearly identified as a recurrent problem. However, this parameter has systematically been underestimated in most of the experiments devoted to understanding the functioning of prehistoric projectile implements. If detailed information is provided on the lithic tools used, their production method, the shaft and the modes of propulsion, scant information is given on the adhesives involved in the hafting process and almost nothing is indicated about their method of manufacture. A simple mention of glue, mastic or vegetable resin, without further information, is sometimes provided (Geneste and Plisson 1990; Soriano 1998; Borgia 2008). Birch bark tar was used in a few experiments (Fischer et al. 1984; Pétillon et al. 2011), but nothing is known about the method of adhesive making, which can influence its properties, such as viscosity and adhesion (Regert et al. 2006). Most of the papers mention an adhesive made using a mixture of resin, beeswax and ochre (Moss and Newcomer 1982; Cattelain and Perpère 1993; O'Farrell 2004; Yaroshevich et al. 2010). Pine resin, or a mixture of pine resin and beeswax, is also mentioned (Barton and Bergman 1982; Bergman and Newcomer 1983; Geneste and Plisson 1986; Caspar and De Bie 1996; Crombé et al. 2001). 
Other authors have employed commercial materials such as carpenter's glue, Elmer's glue or a cyanoacrylate adhesive (Odell and Cowan 1986; Pokines 1998; Pargeter 2007; Sisk and Shea 2009). Beeswax (Iovita et al. 2014) or bitumen, sometimes mixed with a mineral temper, were also used (Beyries and Plisson 1998). Unfortunately, no more indications are supplied on the kind of resin used, the proportion of these natural substances or the parameters used for making the mixture (temperature and time). When the ratio of the different ingredients is provided, pine resin is always the main substance used to produce the adhesive, from $50 \%$ to $80 \%$ of the mixture, as seen in Table 1, which presents a summary of the different adhesives that have been used in shooting experiments.

To overcome the weak aspect of experiments on projectile points and to provide new information on the properties of glue dedicated to hafting lithic barbs on spears, we have developed experiments allowing control of the adhesive composition, measurement of its mechanical properties in relation to the geometry of the projectiles and the study of their ballistic characteristics. The choice of the materials used for making the adhesive was crucial: it was necessary to choose substances that were available in large quantities, that could easily be used for reproducible experiments and for which we could measure the physical properties. With these considerations, pine resin or, more precisely its solid fraction that is commercially available as rosin, also called 'colophany', was estimated to be a good candidate because large quantities can be obtained, which allows the repetition of the experiments with no variation in the raw material. However, its very brittle behaviour impedes its use for applications involving high stress or a high deformation rate. Beeswax, a plasticizer already used in several experiments (Table 1), was thus added (Regert et al. 2001). This binary blend has been preferred to a more classical ternary blend, as the role played by ochre is not fully clarified. To this end, a blend of beeswax and rosin constitutes an adhesive model, allowing a study of lateral microlith efficiency with good reproducibility.

The classical way to study adhesion consists in the use of standard mechanical testing, such as peeling, shear, traction or cleavage tests (Darque-Ceretti and Felder 2003; Da Silva and Adam 2005; Cognard et al. 2011), which are quite difficult to implement between a piece of wood and a flint stone surface. Initially, shear tests have been performed by joining two pieces of wood, or a piece of wood and a flint stone, with an adhesive pad (Gaillard et al. 2013). However, this type of test does not allow scanning of the behaviour of the entire range of rosin concentration contained in the adhesive blend, from pure beeswax to pure rosin. In fact, a pure rosin adhesive pad appears to be too brittle to be tested, while adhesive pads made using blends containing less than $50 \mathrm{wt} \%$ rosin are not sufficiently adhesive. Furthermore, this type of test does not exactly reproduce the type of stress suffered by the microlith during the shooting of the arrow, as the lateral armatures are really locked up inside the adhesive blend. Therefore, in order to characterize the constitutive law of rosin as a function of beeswax content, bulk compression tests have been performed. In particular, results in terms of strain rate dependency and strain hardening are presented here.

In order to study the adhesion behaviour in real use conditions, ballistic experiments have also been performed. Within the framework of an experimental programme on Mesolithic projectile points already started a few years ago (Chesnaux 2008, 2013), we decided to haft the composite tips already available with adhesive corresponding to controlled mixtures of rosin and beeswax. Transparent gelatin targets (Waguespack et al. 2009; Iovita et al. 2014) as well as realistic targets (flesh and bones) were shot at using these replicas of prehistoric arrows equipped with lateral microlithic armatures glued using rosin adhesives with varying beeswax concentrations.

In this paper, we show how the new experimental protocol established, based on controlled adhesive, on ballistic experiments and on the measurement of mechanical parameters, 
Table 1 A summary of the different adhesive recipes used for hafting lithic implements on wooden shafts in various experiments (adapted from Rots and Plisson 2014)

\begin{tabular}{|c|c|c|c|}
\hline Reference & Page & $\begin{array}{l}\text { Replicas of archaeological } \\
\text { implements used }\end{array}$ & Adhesives used \\
\hline Allain and Rigaud (1989) & 222 & Magdalenian implements & $\begin{array}{l}\text { Beeswax }(1 / 4)+\text { resin }(3 / 4)+\text { ochre } \\
\text { (no precision on the amount added) }\end{array}$ \\
\hline Arndt and Newcomer (1986) & 166 & $\begin{array}{l}\text { Bone projectile points from the } \\
\text { Upper Palaeolithic }\end{array}$ & $\begin{array}{l}\text { Mixture of pine resin }(4 / 5) \text { and } \\
\text { beeswax }(1 / 5)\end{array}$ \\
\hline Barton and Bergman (1982) & 239 & Firing copies of Mesolithic points & $\begin{array}{l}\text { Pine resin mixed with beeswax and } \\
\text { animal sinew }\end{array}$ \\
\hline Bergman (1987) & 119 & $\begin{array}{l}\text { Bone and antler points from Ksar } \\
\text { Akil, Lebanon (Upper } \\
\text { Palaeolithic) }\end{array}$ & $\begin{array}{l}\text { Use of pine resin mixed with } \\
\text { beeswax and sinew }\end{array}$ \\
\hline Bergman and Newcomer (1983) & 240 & $\begin{array}{l}\text { Ksar Ali points (Upper } \\
\text { Palaeolithic, Levant) }\end{array}$ & Pine resin and beeswax \\
\hline Beyries and Plisson (1998) & 10 & $\begin{array}{l}\text { Levantine Mousterian thrusted } \\
\text { spear }\end{array}$ & $\begin{array}{l}\text { Bitumen and mixture of bitumen } \\
\text { with a mineral temper }\end{array}$ \\
\hline Borgia (2008) & 56 & Italian Gravettian tools & Glue \\
\hline Caspar and De Bie (1996) & 442 & $\begin{array}{l}\text { Late Palaeolithic arch-backed flint } \\
\text { pieces }\end{array}$ & Pine resins and/or animal sinew \\
\hline Cattelain and Perpère (1993) & 9 & La Gravette points & $\begin{array}{l}\text { Mixture of pine resin, beeswax and } \\
\text { ochre }\end{array}$ \\
\hline Crombé et al. (2001) & 258 & Early Mesolithic microliths & Pine resin \\
\hline Fischer et al. (1984) & 22 (fig. 3) & $\begin{array}{l}\text { Brommian points and transverse } \\
\text { arrowheads (late glacial period) }\end{array}$ & 'Bitumen extracted from birch bark' \\
\hline Geneste and Plisson (1990) & 305 & Shouldered Solutrean points & Vegetable glues and sinew \\
\hline Iovita et al. (2014) & 75 & $\begin{array}{l}\text { Triangular flakes (Levallois } \\
\text { points) used as arrowheads }\end{array}$ & Natural beeswax \\
\hline Márquez and Muñoz (2008) & 380 & $\begin{array}{l}\text { Barbed and tanged arrowhead of } \\
\text { extra-Cantabrian Solutrean }\end{array}$ & $\begin{array}{l}\text { Mixture of pine resin }(50 \%) \\
\text { beeswax }(30 \%) \text { and ochre }(20 \%)\end{array}$ \\
\hline Moss and Newcomer (1982) & 292 & Palaeolithic tools & Mixture of pine resin and beeswax \\
\hline Odell and Cowan (1986) & 199 & $\begin{array}{l}\text { Shaped and unmodified chert tips } \\
\text { hafted on to arrow and spear } \\
\text { shafts }\end{array}$ & $\begin{array}{l}\text { 'Natural hemp and a mastic of } \\
\text { Elmer's glue' }\end{array}$ \\
\hline O’Farrell (2004) & 125 & La Gravette points & $\begin{array}{l}\text { Mixture of pine resin, beeswax and } \\
\text { ochre }\end{array}$ \\
\hline Pargeter (2007) & 148 & Lithic Howiesons Poort segments & Commercially cyanocrylate glue \\
\hline Pétillon et al. (2011) & 1279 & $\begin{array}{l}\text { Magdalenian composite projectile } \\
\text { tips }\end{array}$ & $\begin{array}{l}\text { Two types of adhesives: Beeswax, } \\
\text { resin and ochre; Birch bark pitch }\end{array}$ \\
\hline Pokines (1998) & 876 & $\begin{array}{l}\text { Cantabrian Lower Magdalenian } \\
\text { antler projectile points }\end{array}$ & Commercial carpenter glue \\
\hline Shea et al. (2001) & 809 & Levallois points & $\begin{array}{l}\text { Synthetic paving tar considered as a } \\
\text { substance with properties similar to } \\
\text { those of bitumen }\end{array}$ \\
\hline Sisk and Shea (2009) & 2041 & $\begin{array}{l}\text { Triangular flakes (Levallois } \\
\text { points) used as arrowheads }\end{array}$ & Commercial adhesive \\
\hline Soriano (1998) & 84 & Perigordian microgravettes & Mastic as general term \\
\hline Stodiek (2000) & 73 & Magdalenian antler points & $\begin{array}{l}\text { Mixture of pine resin and beeswax } \\
\text { (in a proportion of } 2: 1 \text { ) }\end{array}$ \\
\hline Yaroshevich et al. (2010) & 371 & $\begin{array}{l}\text { Microlith implemented projectiles } \\
\text { during the Middle and the Late } \\
\text { Epipalaeolithic of the Levant }\end{array}$ & $\begin{array}{l}\text { 'Mixture of beeswax and resin with } \\
\text { the addition of either gypsum } \\
\text { powder of ochre powder as filling' }\end{array}$ \\
\hline
\end{tabular}


provides new answers to two embedded questions. Our main objectives were as follows: first, to understand the relation between adhesive strength and its efficiency, depending on the adhesive composition and the velocity of the projectile (in fact, blends of beeswax and rosin are known to exhibit both viscoelastic and viscoplastic behaviours: Gaillard et al. 2013); and, second, to assess the influence of the adhesive on the effectiveness of lateral armatures in terms of the damage produced on the target. At the same time, we wanted to determine the role of projectile geometry on the capacity of the lateral microlithic armatures to lacerate the flesh. The results clearly emphasize the role played by the lateral armatures in terms of target damage and penetration. It is also demonstrated that blends of rosin and beeswax are completely plausible for this kind of adhesive application. In particular, it is shown that the most intuitive mixture, which consists in blending more resin than beeswax, is far from obvious, and that the optimal mixture is made of $70 \mathrm{wt} \%$ beeswax with $30 \mathrm{wt} \%$ rosin, an unexpected and fundamental result for conducting further experiments with firmer hafting adhesives, an essential condition for performing reliable and reproducible shooting tests.

\section{EXPERIMENTAL DETAILS}

\section{Manufacture of the composite projectile implements}

Replicas of prehistoric projectiles were prepared as follows. Pine wood arrows, $800 \mathrm{~mm}$ long and $8 \mathrm{~mm}$ in diameter, were cut and then grooved in order to receive the adhesive in its melted form and the microliths (Fig. 1). The microliths are locked up by the adhesive inside the channel, highlighting the fact that the adhesion of the microlith to the arrow is not only based on the adhesive capability of the blend on wood or flint, but also on the capability of the blend to resist high-velocity deformation. Indeed, the characterization of the constitutive law governing the mechanical behaviour of the adhesive appears to be fundamental.

The microliths were produced by one of us (LC) following current methods of manufacture known for Sauveterrian microliths from the Mesolithic period of the South of France (Guilbert 2001;

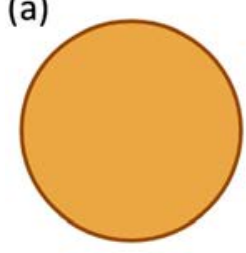

(b)

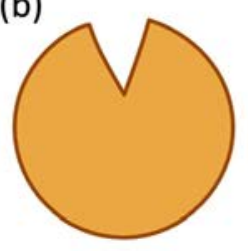

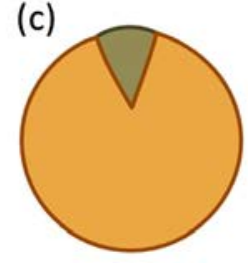

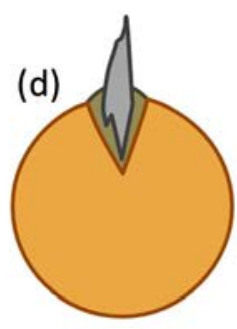

(e)

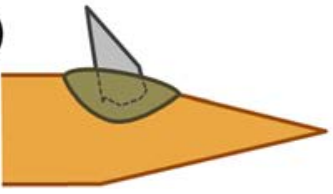

(f)

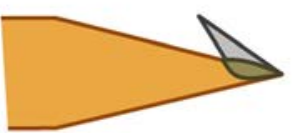

(g)

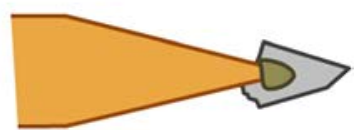

Figure 1 The preparation of the prehistoric projectiles. The initial arrow $(a)$ is grooved $(b)$, then the groove is filled with melted adhesive $(c)$ and finally the microlith is put into place $(d)$. Part $(e)$ shows a cross-section of the obtained arrow. Parts $(f)$ and $(g)$ show two different ways to arm an arrow with a flint stone at its extremity. In ( $f$ ), a lateral microlith is used, while for $(g)$ it is an axial flint stone. 
Chesnaux 2008; Michel 2011): bladelets were truncated, rubbed or brusquely retouched using a roe deer antler. The choice was to focus on three types of barbs-triangles, segments and points -with weights between 0.2 and $0.4 \mathrm{~g}$.

Both lateral and/or axial microliths were mounted on different arrows, based on the rare archaeological projectile tips preserved in Swedish peat bogs, such as the arrow of Lushult (Rozoy 1978) and that of Rönneholm (Larsson and Sjöström 2011). Figure 2 presents the differing geometries of the arrows. Lateral microliths were fixed on continuous rows, following one to four axes. The tips of the arrows were made of either carved wood (Figs. 2 (a) and 2 (f) -2 (i)) or axial microliths (Figs. 2 (b) -2 (e) and 2 (j)).

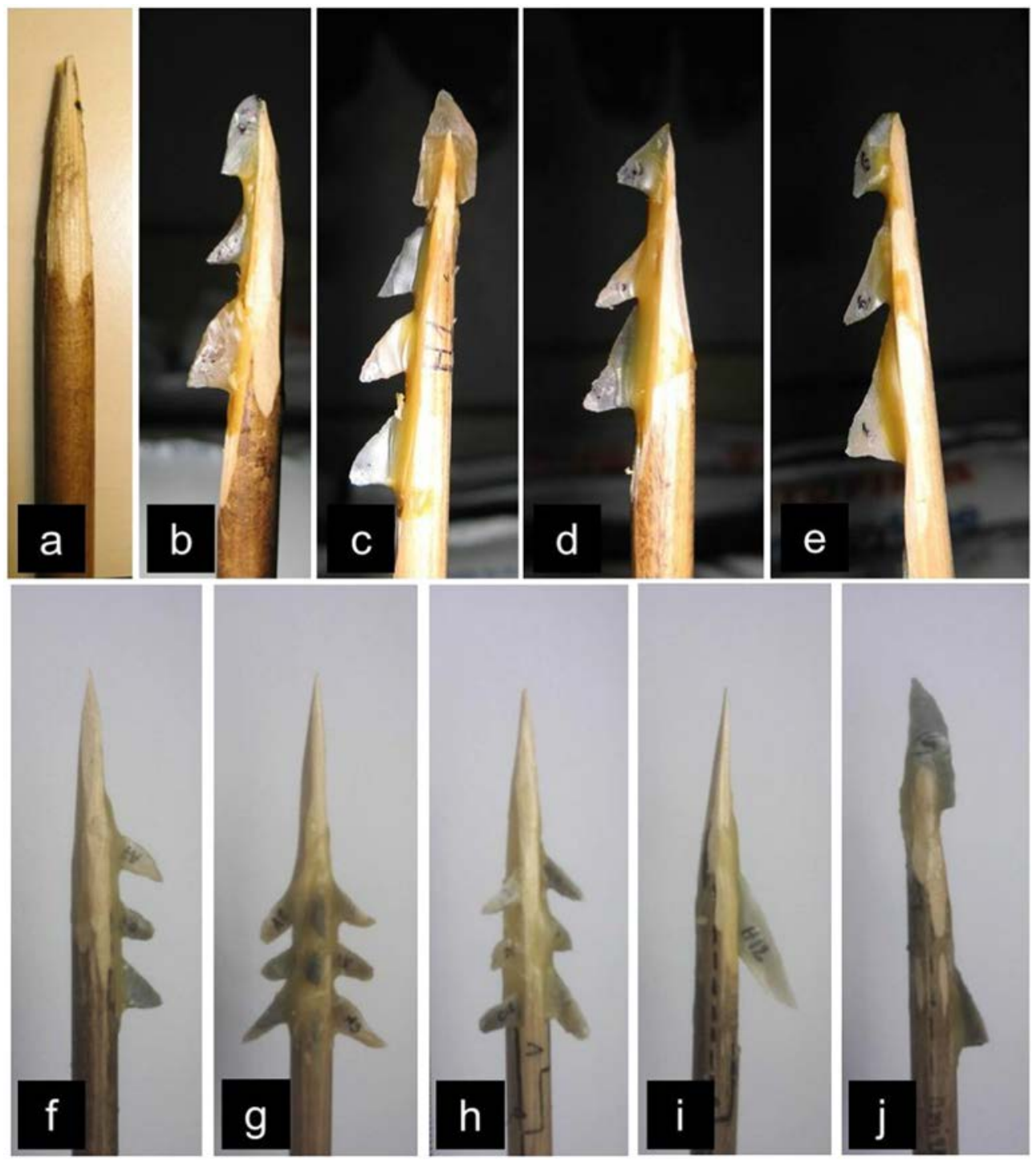

Figure 2 Examples of different arrow geometries. 
The raw materials used for the manufacture of the adhesive were rosin and beeswax, purchased from a professional apiarist (http://ets-leygonie.net). Rosin consists of the solid fraction resulting from pine resin distillation; it was obtained as a block of translucent resin, which was softened by heating. Gas chromatographic analysis of the raw products showed that the two materials used were pure substances, free of additives.

Blends were prepared with differing proportions of rosin and beeswax. The rosin concentration is expressed in terms of weight and the blends are referenced as 10,20 or $30 \mathrm{wt} \%$, and so on. It is imperative to control the composition of the binary blend precisely. In fact, it has been shown in Gaillard et al. (2013) that the mechanical behaviour of the adhesive, and particularly its strain rate sensitivity, is closely related to the rosin concentration.

In this blend, the rosin constitutes the adhesive part while the beeswax is added as a plasticizer. Beeswax and rosin are two materials that have melting points close to room temperature. In particular, beeswax has a melting point located between 60 and $65^{\circ} \mathrm{C}$, but presents several polymorphic transitions before this temperature (Kameda 2005; Kameda and Tamada 2009). The first of these transitions occurs at $43^{\circ} \mathrm{C}$ and can be considered as the softening point of the material (the mechanical properties of the material start to decline catastrophically from this temperature). This means that beeswax can be shaped starting from $43^{\circ} \mathrm{C}$, a temperature that can be easily reached by the friction between two hands. Concerning rosin, a flame is generally necessary to obtain a material with a 'liquid' consistency, its softening point reportedly being around $70^{\circ} \mathrm{C}$.

The melting of the differing blends was realized at $100^{\circ} \mathrm{C}$ to ensure the uniformity of the blends, as described in previous work (Gaillard et al. 2011, 2013).

\section{Mechanical testing}

Compression testing was preferred to traction testing. In fact, the manufacturing of samples for traction testing appears to be impossible. The compression tests were performed using an Erichsen apparatus. Cylindrical samples with a diameter of $8 \mathrm{~mm}$ and a height of $10 \mathrm{~mm}$ were deformed. A release agent was used between the sample and the plates of the machine to reduce friction. Samples of all the blends were prepared by moulding except for pure rosin, which seems to be too brittle. Differing constant testing velocities ranging from 0.0015 to $1 \mathrm{~mm} \mathrm{~s}^{-1}$ were used. The true deformation of the sample height was followed and measured in situ by contactless extensometry (tracking points on compression plates) during the test, using a camera at a frequency of $33 \mathrm{~Hz}$.

The true stress, $\sigma$, and strain, $\varepsilon$, were defined as follows, assuming an incompressible material and uniform deformation:

$$
\sigma=\frac{F}{S(t)}
$$

and

$$
\varepsilon=\ln \left(\frac{l(t)}{l_{0}}\right)
$$

where $F$ is the force applied on the sample, $l_{0}$ is the initial height of the sample, $l(t)$ is the height of the sample measured in situ during the compression test, and $S(t)$ is the in-situ section of the sample assuming volume conservation resulting from the incompressibity hypothesis. 
In order to determine the strain rate sensitivity $m$ and also the strain hardening coefficient $h_{g}$ of the different blends, stress-strain curves were fitted following a G'Sell and Jonas behaviour (G'Sell and Jonas 1979). The following law was used:

$$
\sigma=\sigma_{0} e^{h_{g} \varepsilon^{u}} \dot{\varepsilon}^{m},
$$

where $\sigma_{0}$ is the yield stress and $\dot{\varepsilon}$ is the strain rate:

$$
\dot{\varepsilon}=\frac{1}{l(t)} \frac{\mathrm{d} l(t)}{\mathrm{d} t} .
$$

\section{High-velocity testing}

To reproduce the real stress conditions of the adhesives at high velocities, a bow was instrumented in order to produce reproducible results in terms of the trajectory and the resulting velocities of the arrows. Furthermore, a base was built to support the bow. Through the use of a mechanical arm, this original instrument allows the measurement of the force exerted on the bow string but, above all, it allows reproducible shots at a $25 \mathrm{~cm}^{2}$ target $(5 \times 5 \mathrm{~cm})$. A high-velocity camera was used to determine the velocities of the projectiles. Arrow shots were recorded at 1200 images per second. The impacts of the arrows were filmed both in profile and in full face. Typical arrow velocities were calibrated as a function of the force applied on the string. A schematic and a photograph of this original experimental device are shown in Figure 3.

In order to model the consistency of the animal, bovine gelatin was used, as is usual practice in terminal ballistics. Bovine gelatin for pastry use was purchased and prepared at a concentration of $10 \mathrm{wt} \%$ by adding hot water (at $65^{\circ} \mathrm{C}$ ). The resulting melt was cooled to $4^{\circ} \mathrm{C}$ over a period of several hours, until it reached its 'solid' state. Shots were fired at the target at the temperature of $4^{\circ} \mathrm{C}$. The resulting target is semi-transparent, allowing in-situ observation of the arrow penetration. Two types of target were used. First, thin 3 litre targets were used in order to record the penetration

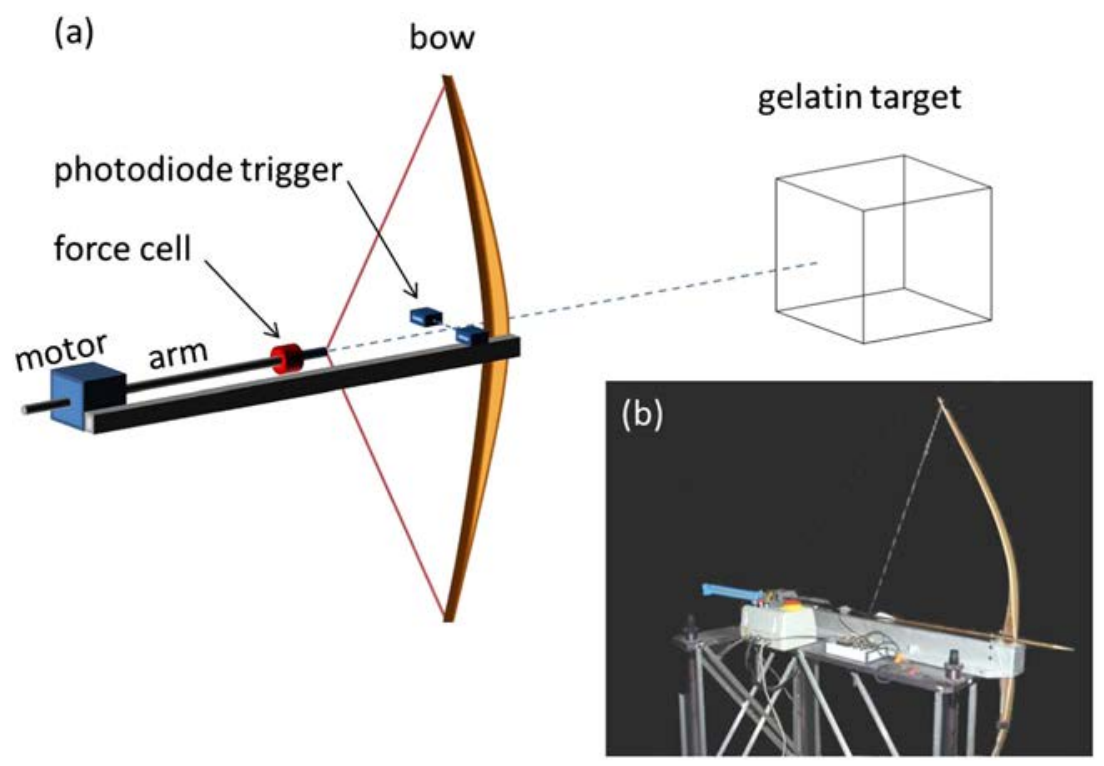

Figure 3 A schematic (a) and a photograph (b) of the typical device used for the ballistic tests. 
of the arrows in a cross-sectional fashion, using the high-velocity camera. Next, 10 litre targets were used for quantitative experiments. For each shot, the penetration of the arrows into the targets was measured. The detachment of microliths from the arrows was recorded as the damage criterion.

RESULTS AND DISCUSSION

The constitutive laws of the different blends

Figure 4 presents typical stress-strain curves obtained for the $70 \mathrm{wt} \%$ and $90 \mathrm{wt} \%$ blends at different compression velocities, $\mathrm{d} l / \mathrm{d} t$, of $1,0.1,0.01$ and $0.0015 \mathrm{~mm} \mathrm{~s}^{-1}$. It is clearly
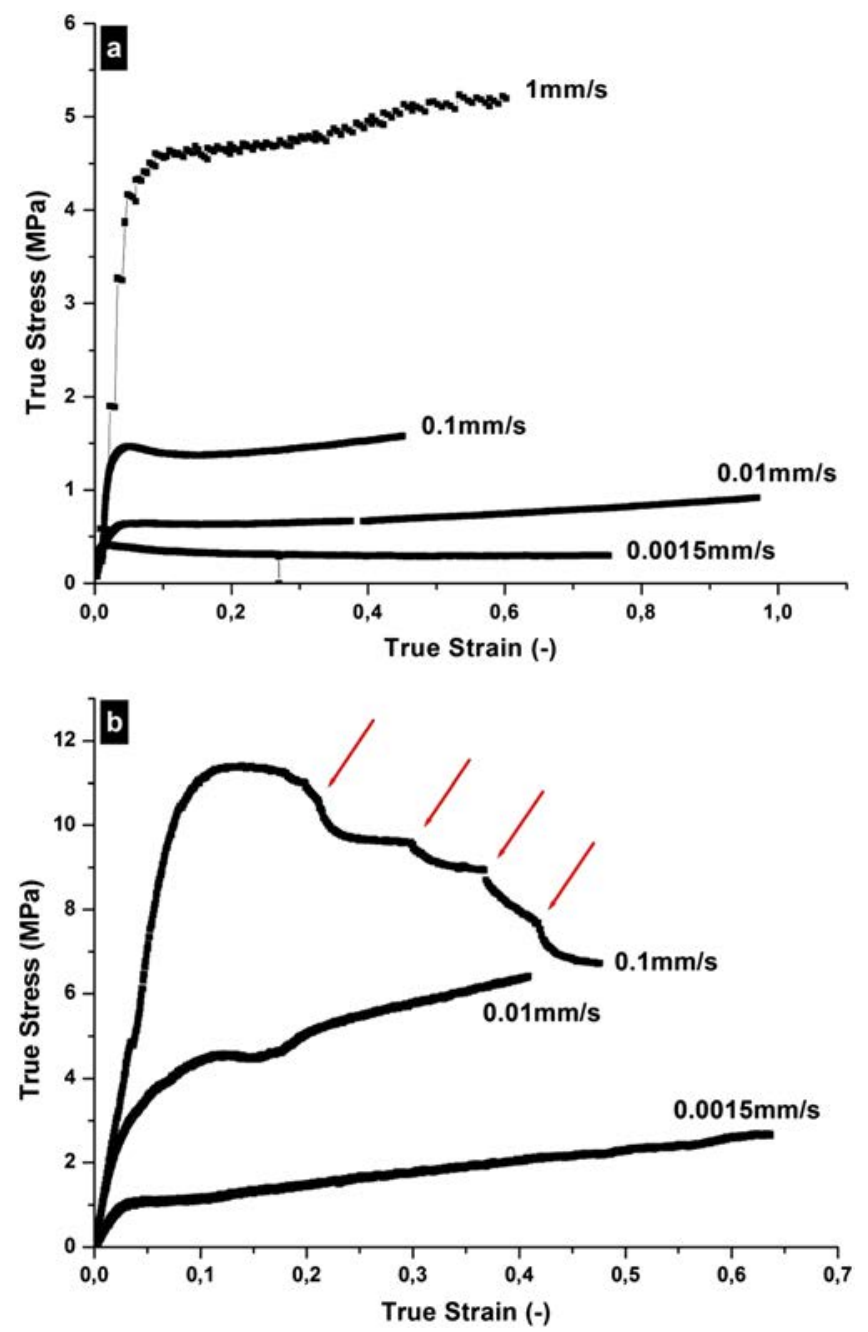

Figure 4 Typical stress-strain curves obtained in compression at different velocities for the 70 wt\% (a) and the 90 wt $\%$ (b) blends. Catastrophic failures observed in the $90 \mathrm{wt} \%$ blend are marked by arrows. 
observed that the faster the material is deformed, the harder it becomes, revealing a pronounced viscous behaviour. In particular, the strain rate sensitivity $m$ has been determined following the relation

$$
m=\frac{\mathrm{d} \log \sigma}{\operatorname{dlog} \varepsilon} .
$$

This exponent $m$ is equal to 0.37 in the case of the $70 \mathrm{wt} \%$ blend, revealing a mechanical behaviour that is strongly dependent on the deformation velocity. The strain rate sensitivity $m$ has been determined for all the blends (see Fig. 5) and it appears to be closely related to the rosin content. Apparently, $m$ increases with the rosin content from 0.15 in the case of pure beeswax to 0.5 for the $90 \mathrm{wt} \%$ blend. These results are completely in accordance with the previous ones obtained by nanoindentation and shear testing (Gaillard et al. 2013), validating the use of compression testing to characterize the strain rate sensitivity. Table 2 summarizes the values of the yield stress and the strain rate sensitivity for all the blends. These strain rate sensitivities can be explained by the proximity of the melting points and the polymorphic transitions of the beeswax fraction from room temperature. In fact, solids become generally more viscous as the temperature increases. In Gaillard et al. (2011), it has been shown that the melting points and also the temperatures of phase transition of the blends decrease as the rosin content increases, thus explaining why the strain rate sensitivity increases at the same time.

Figure 6 shows the experimental results for all the blends obtained at $0.01 \mathrm{~mm} \mathrm{~s}^{-1}$, normalized with respect to the yield stress, $\sigma_{0}$, and the term related to the strain rate sensitivity, $\dot{\varepsilon}^{m}$. Finally, the curves shown in Figure 6 depend only on the strain hardening. The line $\sigma /\left(\sigma_{0} \dot{\varepsilon}^{m}\right)=1$ corresponds to the limit between the hardening and softening domains. It is observed that only the three blends containing more than $70 \mathrm{wt} \%$ of rosin harden with deformation. All the other blends present a softening behaviour.

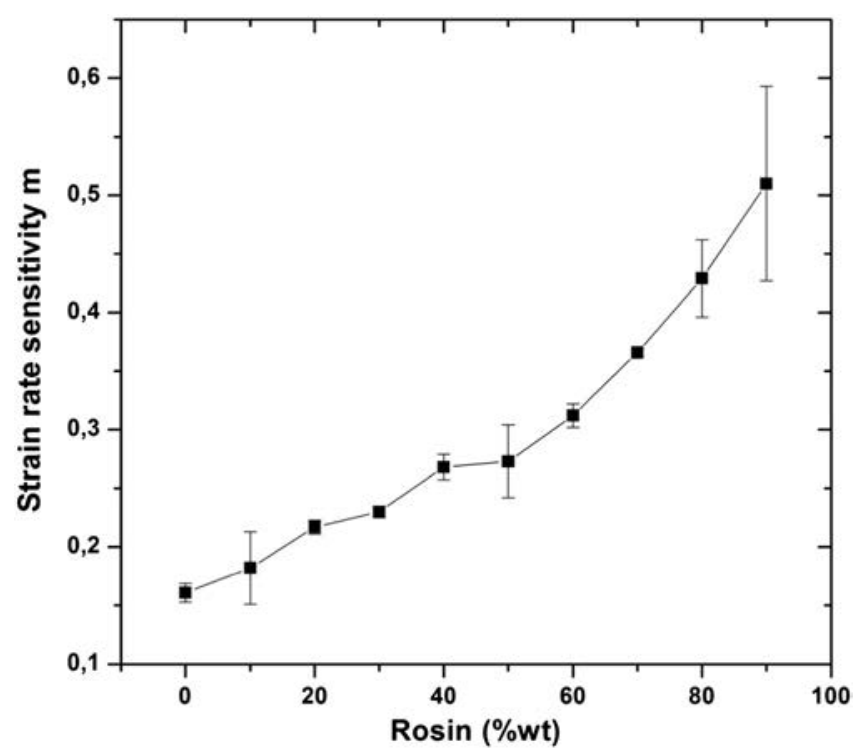

Figure 5 The evolution of the strain rate sensitivity as a function of the rosin content in the different blends. 
Table 2 The yield stress (MPa) for a compression velocity of $0.01 \mathrm{~mm} \mathrm{~s}^{-1}$ and strain rate sensitivity values as a function of the rosin content (wt\%) in the blend

\begin{tabular}{lcc}
\hline \hline Rosin content $(w t \%)$ & Yield stress $(\mathrm{MPa})$ & $m$ \\
\hline 0 & 0.97 & 0.16 \\
10 & 0.7 & 0.18 \\
20 & 0.57 & 0.22 \\
30 & 0.42 & 0.23 \\
40 & 0.54 & 0.27 \\
50 & 0.46 & 0.27 \\
60 & 0.38 & 0.31 \\
70 & 0.64 & 0.37 \\
80 & 0.83 & 0.43 \\
90 & 4.62 & 0.51 \\
\hline \hline
\end{tabular}

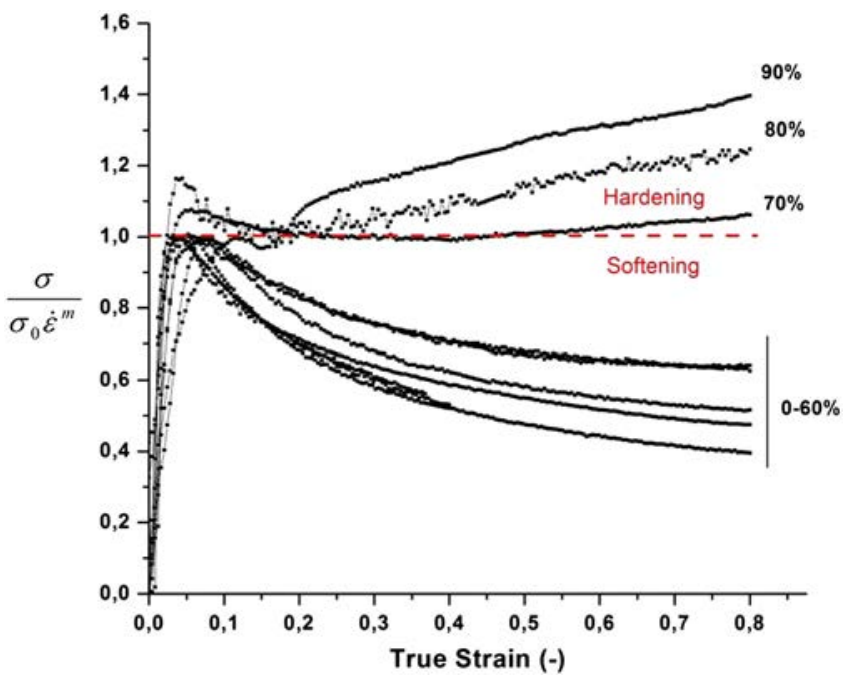

Figure 6 Normalized stress-strain curves $\left(\sigma / \sigma_{0} \dot{\varepsilon}^{m}\right)$, showing the strain hardening exhibited by the 70,80 and 90 wt\% blends and the softening of the other blends. In particular, two domains are clearly observed, the softening one below $\sigma / \sigma_{0} \dot{\varepsilon}^{m}=1$ and the hardening domain for $\sigma / \sigma_{0} \dot{\varepsilon}^{m}>1$.

Finally, the following preliminary conclusions can be drawn. The rosin content clearly influences the mechanical behaviour of the blends. The higher the rosin content, the higher are the strain rate sensitivity and the strain hardening, inducing a weakness at high velocity for a high rosin content, as can be observed for the $90 \mathrm{wt} \%$ blend in Figure 4. This weakness at a high deformation velocity is particularly interesting, as it shows that some blends become brittle at a high deformation rate. These results provide a first pattern on the influence of the strain rate and beeswax content on the mechanical performance. However, it should be noted that 
the mechanical behaviour of the adhesive blends at velocities close to the real ones-that is, close to $40 \mathrm{~m} \mathrm{~s}^{-1}$ — may be completely different from that deduced from the compression testing.

\section{Ballistics tests on gelatin: high-speed testing}

As the maximum deformation velocity studied with the compression test is $1 \mathrm{~mm} \mathrm{~s}^{-1}$, shots were fired at gelatin targets in order to investigate the adhesives in real velocity conditions. Several tests, using different arrows, were realized using the same arrow geometry, with three lateral microliths (as shown in Fig. 2 (f)). All the adhesive blends were probed for differing arrow velocities, between 30 and $50 \mathrm{~m} \mathrm{~s}^{-1}$. As mentioned in the experimental section, the loss of one or more lateral microliths was recorded as the damage criterion. The example given in Figure 7 shows the impact in the gelatin target of the arrow with microliths fixed with pure beeswax. Only one of the three microliths remains fixed to the arrow. With regard to the two other microliths, the first one is found about $20 \mathrm{~mm}$ inside the target, while the second one does not even penetrate the target. From this kind of experiment, a mapping of the adhesion of the microliths as a function of the composition of the blends and the velocities of the arrows has been established. Forty-four tests were necessary to encompass the various rosin concentrations and arrow velocities. The results are presented in Figure 8. As observed during the compression testing, the blends with a high rosin content, up to $90 \mathrm{wt} \%$, exhibit a brittle behaviour for velocities up to $30 \mathrm{~m} \mathrm{~s}^{-1}$. However, the brittle behaviour appears to evolve with the arrow velocity. In particular, a number of blends that shows good adhesion at $30 \mathrm{~m} \mathrm{~s}^{-1}$ appear to be brittle at $50 \mathrm{~m} \mathrm{~s}^{-1}$. This is the case for the 50,60, 70 and $80 \mathrm{wt} \%$ blends. In this way, two domains, adhesion and weakness, can be clearly distinguished in Figure 8. The most efficient blends are those between 20 and $40 \mathrm{wt}$ $\%$; that is, the blends containing more plasticizer (beeswax) than adhesive agent (rosin).

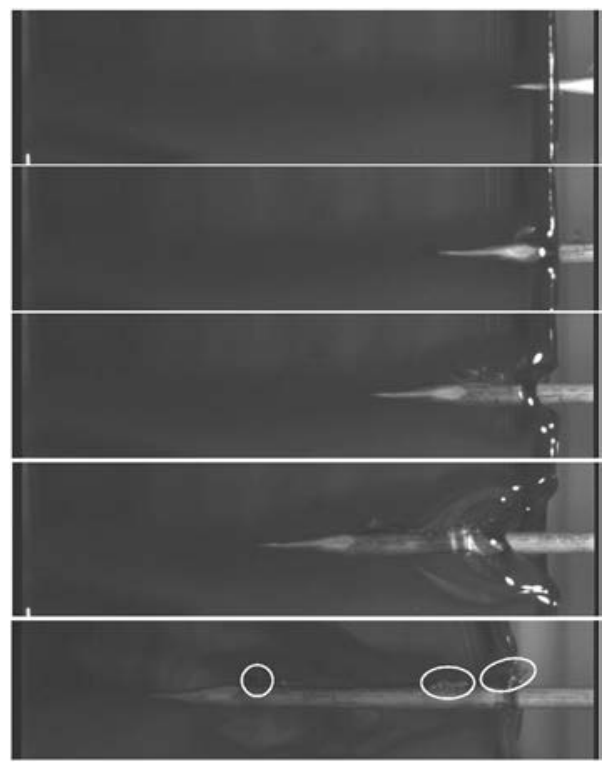

Figure 7 Video sequences of the impact of the arrow having three lateral microliths affixed using pure beeswax. The white circles and ellipses show the positions of the three lateral microliths after the shot. 


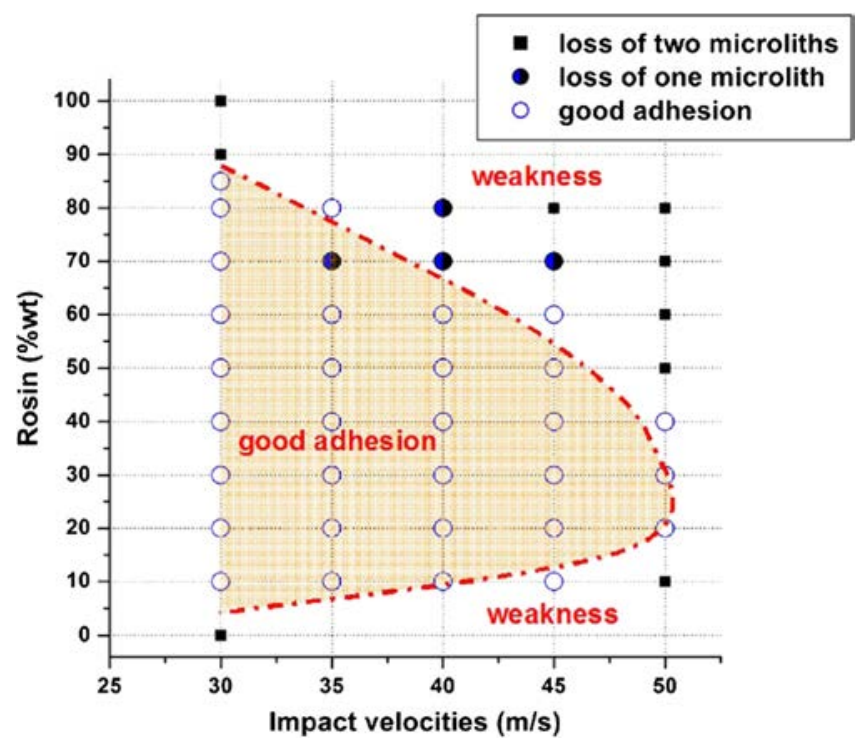

Figure 8 An adhesion diagram established from the shooting experiments and showing the adhesion of the microliths and the weakness domains as a function of the impact velocities and rosin content.

In what follows, the role played by the lateral microliths will be examined. In a first analysis, all the arrow geometries summarized in Figure 2 were investigated. For all these arrows, the same velocity of $35 \mathrm{~m} \mathrm{~s}^{-1}$ and the same blend have been used — that is, the $30 \mathrm{wt} \%$ blend - to avoid any adhesive failure during the test. Penetration lengths were measured for each shot and compared to those obtained previously at the same velocity for arrows having three lateral microliths fixed along a single axis. Table 3 summarizes these penetration lengths. Compared to the sharpened arrows without microliths (Fig. 2 (a)), the efficiency of the lateral microliths (Figs. 2 (f) -2 (i)) in terms of the penetration length is clearly observed. An increase of about $15-20 \mathrm{~mm}$ is obtained; that is, $11 \%$ more than the $135 \mathrm{~mm}$ of penetration obtained using the arrow without any lateral microliths (Fig. 2 (a)). Nevertheless, the number of these lateral armatures does not seem to play an important role in the penetration length of the arrow. The presence of 12 microliths even appears to correspond to a less efficient shot among those obtained with lateral armatures. It is also observed that the arrow armed with an axial microlith at its extremity is the most effective, with a penetration length of $165 \mathrm{~mm}$.

Table 3 The penetration lengths ( $\mathrm{mm}$ ) obtained for different arrow geometries 
Besides the penetration length, residual damage on the gelatin targets was also closely examined. Figure 9 presents photographs of the impacted gelatin targets and the corresponding arrow geometry. The presence of cracks is clearly related to the presence of lateral microliths, demonstrating the efficiency of the lateral microliths with regard to the shredding of the target. The videos presented in the supplementary online material provide clear examples of the lacerations caused by the arrow armed with 12 lateral microliths (Fig. 2 (g)) compared to the one without any lateral armatures (Fig. 2 (a)). It is particularly interesting to note that if the efficiency of the 12 microliths is not evidenced in terms of the residual penetration length, it is clearly observed that the damage left on the target is more significant if the microliths are placed along different axes on the arrow. Therefore, these two criteria, the penetration length and the damage, should be recorded in order to evaluate the potentiality of the different arrow geometries.

\section{Inspection of the results obtained with a realistic target}

If the arrow geometries associated with this adhesive blend are efficient with regard to causing damage on bovine gelatin targets, what about a realistic target with skin and bones? In this regard, shots have also been fired at a boar's shoulder, in order to corroborate the efficiency of the projectiles. As mentioned above, the major difference between a gelatin target and a real piece of boar's meat is the presence of skin and bones. The boar's skin measures about $8 \mathrm{~mm}$ in thickness, and comprises epidermis, dermis and hypodermis. The thick hair and leathery skin in particular constitute an impermeable barrier for the penetration of soft projectiles.

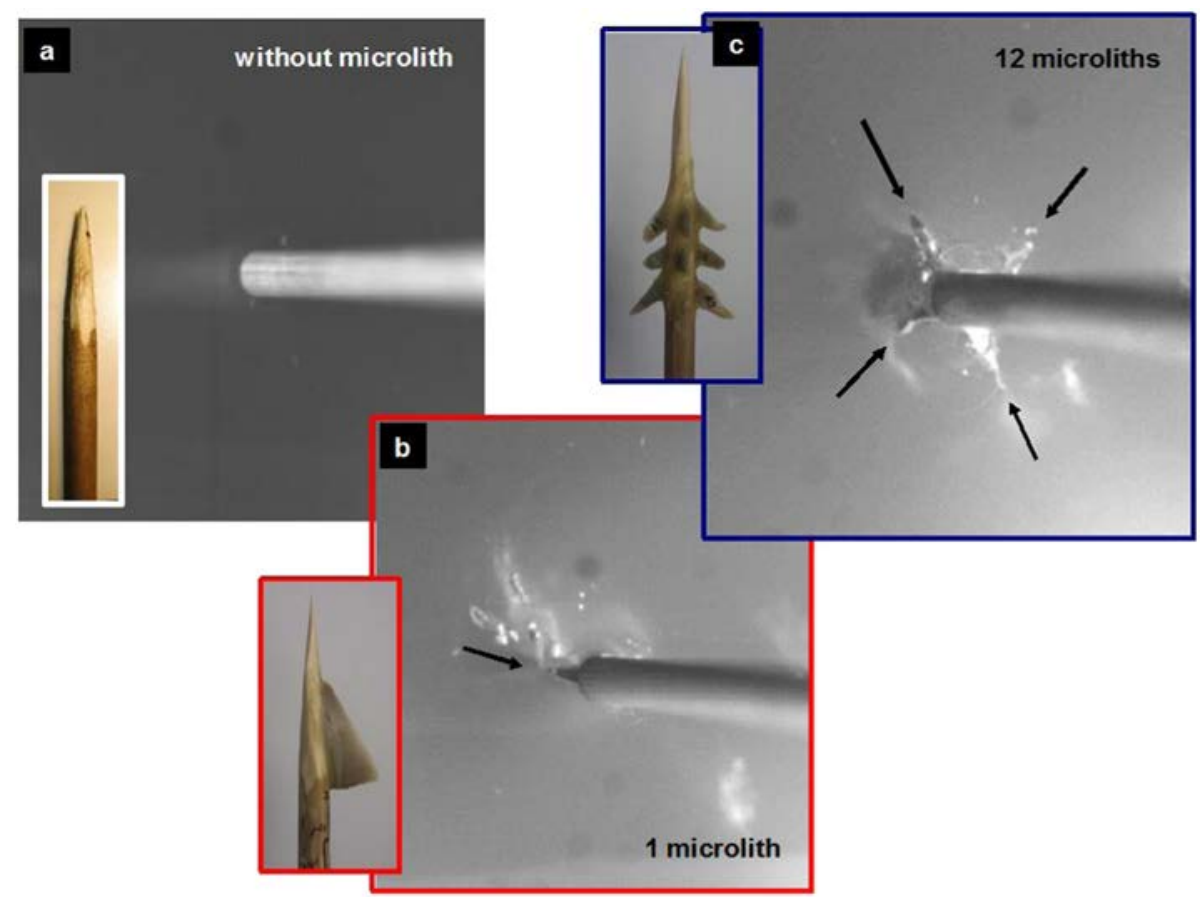

Figure 9 Impacted gelatin with different arrow geometries: sharpened wood without any microliths (a), with one lateral microlith (b) and with 12 lateral microliths (c). 
For comparison, at $35 \mathrm{~m} \mathrm{~s}^{-1}$ sharpened arrows without microliths penetrate about $135 \mathrm{~mm}$ into the gelatin target, while inside the boar's flesh the penetration value remains fixed at about $15 \mathrm{~mm}$ (Figure 10 (a)). Therefore, sharpened wood arrows, with or without lateral microliths, as shown in Figs. 2 (a) and 2 (f) -2 (i), penetrate the flesh of the boar with difficulty.

Fixing a microlith on the extremity of the arrows allows the penetration to be improved greatly. The size and location of this microlith are not important, as a lateral microlith fixed at the extremity of the arrow (Figs. 1 (f), 2 (b), 2 (c) and 2 (e)) appears to be just as efficient as an arrow armed with an axial flint stone (Figs. 1 (g), 2 (c) and 2 (j)). In fact, if they do not encounter bones, these arrows can pierce though a shoulder that represents about $100 \mathrm{~mm}$ of flesh, as shown in Fig. 10 (d). The wounds left by the arrows, shown on Figs. 10 (b) and 10 (c), clearly reveal the lacerations due to the microliths. If these results constitute a serious drawback for the validation of gelatin as model material for boar's flesh, particularly because

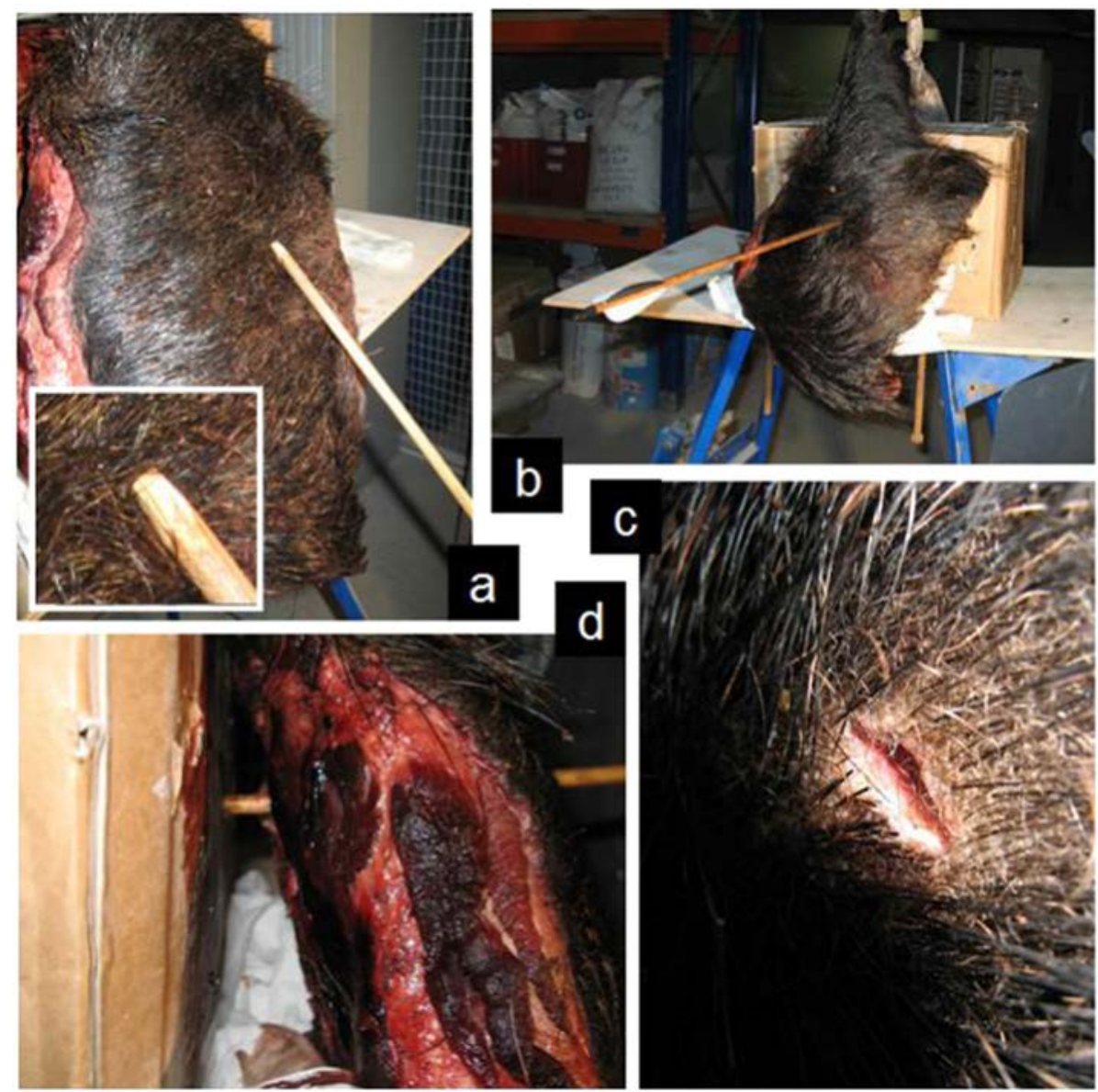

Figure 10 Photographs of the experiments performed on the boar's shoulder. (a) A shot fired with the sharpened arrow without any microliths (Figure 2 (a)), illustrating the difficulty for the arrow to penetrate the skin. (b-d) Shots fired with an arrow armed with three lateral microliths (Figs. $2(b)-2(e)$ ), showing the efficiency of the microliths, particularly with regard to the shredding of both skin and flesh. 
of the lack of skin, they validate the use of arrows presenting both axial and lateral microliths and, above all, they validate the $30 \mathrm{wt} \%$ blend as useful adhesive for this type of application.

\section{CONCLUSIONS}

To the best of the authors' knowledge, this is the first time that such experiments, with careful control of the hafting adhesives and the determination of their properties, have been performed.

A ballistic protocol has been established in order to clearly determine the adhesion properties of different adhesives related to flint stone armatures on arrows, using a new model of a ballistic frame, which is complementary to those that have already been developed (Shea et al. 2001; Waguespack et al. 2009).

The ballistic tests have confirmed the efficiency of the small lateral armatures in enlarging the lacerations of the flesh and so inducing lethal injuries, even at high velocities (several tens of metres per second). Tests performed on real flesh have also shown that these lateral barbs did not help the initial penetration of the arrow into flesh with a thick skin, as in the case of the boar. The critical parameter appears to be the presence of a cutting tool (whatever its size) at the tip of the arrow, to penetrate the skin.

This study has also obviously highlighted the importance of the adhesive composition and properties. In fact, for this particular use at high velocity, the toughness of the adhesive is critical. While rosin presents a high adhesive power, it cannot be used in pure form in such an application: the addition of a plasticizer appears to be necessary. This study confirms that beeswax, which has already largely been used for various experiments (Table 1), is a relevant and viable candidate.

We now expect that the development of the innovative experimental device presented in this paper will be helpful in further attempts to refine our knowledge of the functional and behavioural interpretations of projectile assemblages. The perspective of complicating the protocol by testing various substances for their adhesive properties can now be envisaged. In particular, the role of ochre in a ternary rosin/beeswax/ochre mixture with differing proportions should be studied. The natural variability of pine exudates should be assessed. Birch bark tar, an adhesive known to have been used as a hafting material from Middle Palaeolithic up to more recent periods (Aveling and Heron 1998; Regert et al. 1998; Grünberg et al. 1999; Grünberg 2002; Mazza et al. 2006) should also be tested. It will be then necessary to control the way in which this tar is made, in order to obtain a standardized material in sufficient amounts to perform reproducible and comparable experiments. The role of beeswax in birch bark tar adhesive should also be investigated, since this mixture is archaeologically attested (Regert et al. 2003). Finally, the role of temperature on the properties of these different adhesives should be assessed in order to take winter conditions into account.

To conclude, the question of the hunter-gatherer's arsenal during the Upper Palaeolithic and Mesolithic periods remains fundamental. A detailed study of the functioning of projectile armatures is a favoured way of understanding the technical choices made by prehistoric societies with regard to their weaponry.

\section{ACKNOWLEDGEMENTS}

The authors are very grateful to the ANR (Agence Nationale de la Recherche) and its financial support of the research programme EXSUDARCH dedicated to the chemistry, manufacture and use of plant exudates and tars. We would also like to thank both reviewers for their very fruitful comments. 


\section{REFERENCES}

Allain, J., and Rigaud, A., 1989, Colles et mastics au Magdalénien, in Nature et fonction des foyers préhistoriques (eds. M. Olive and Y. Taborin), 221-3, APRAIF, Mémoires du musée de Préhistoire d'Ile-de-France, 2, Nemours.

Arndt, A., and Newcomer, M. H., 1986, Breakage patterns on prehistoric bone points, in Studies in the Upper Palaeolithic of Britain and Northwest Europe (ed. D. A. Roe), 165-73, BAR International Series, 296, Archaeopress, Oxford.

Aveling, E. M., and Heron, C., 1998, Identification of birch bark tar at the Mesolithic site of Star Carr, Ancient Biomolecules, 2, 69-80.

Barton, R. N. E., and Bergman, C. A., 1982, Hunters at Hengisbury: some evidence from experimental archaeology, World Archaeology, 14(2), 237-48.

Bergman, C. A., 1987, Hafting and use of bone and antler points from Ksar Akil, Lebanon, in La main et l'outil: manches et emmanchements préhistoriques. Table Ronde CNRS tenue à Lyon du 26 au 29 novembre 1984 (ed. D. Stordeur), 117-26, Travaux de la Maison de l'Orient 15, Lyon.

Bergman, C. A., and Newcomer, M. H., 1983, Flint arrowhead breakage: examples from Ksar Akill, Lebanon, Journal of Field Archaeology, 10(2), 238-43.

Beyries, S., and Plisson, H., 1998, Pointes ou outils triangulaires? Données fonctionnelles dans le Moustérien levantin, Paléorient, 24(1), 5-24.

Bon, F., 2009, Préhistoire, la fabrique de l'histoire, L'Univers Historique, Editions du Seuil.

Borgia, V., 2008, Ancient Gravettian in the south of Italy: functional analysis of backed points from grotta Paglicci (Fogia) and grotta della Cala (Salerno), Palethnologie, 1, 45-65.

Caspar, J.-P., and De Bie, M., 1996, Preparing for the hunt in the later Paleolithic camp at Rekem, Belgium, Journal of Field Archaeology, 23(4), 437-60.

Cattelain, P., and Perpère, M.-P., 1993, Tir expérimental de sagaies et de flèches emmanchées de pointes de la Gravette, Archéo-Situla, 17-20, 5-28.

Chesnaux, L., 2008, Sauveterrian microliths: evidence of the hunting weapons of the last hunter-gatherers of the Northern Alps, in Projectile weapon elements from the Upper Palaeolithic to the Neolithic: proceedings of session C83, XVth World Congress UISPP, Lisbon, September 4-9, 2006 (eds. J.-M. Pétillon, M.-H. Dias-Meirinho, P. Cattelain, M. Honegger, C. Normand and N. Valdeyron), Palethnologie, 1, 133-46.

Chesnaux, L., 2013, Microliths from 62 rue Henry-Farman, Paris (15th arrondissement): specific arrows for different types of game hunted in particular places? In Mesolithic palethnography research on open-air sites between Loire and Neckar, proceedings of the international round-table meeting, Paris, November 26-27, 2010 (eds. B. Valentin, B. Souffi, T. Ducrocq, J.-P. Fagnart, F. Séara and C. Verjux), 119-32, Séances de la Société préhistorique française, 2-2, Société préhistorique française, Paris.

Cognard, J. Y., Creac'Hcadec, R., Da Silva, L. F. M., Texeira, F. G., Davies, P., and Peleau, M., 2011, Experimental analysis of the influence of hydrostatic stress on the behaviour of an adhesive using a pressure vessel, Journal of Adhesion, 87, 804-25.

Crombé, P., Perdaen, Y., Sergant, J., and Caspar, J.-P., 2001, Wear analysis on Early Mesolithic microliths from the Verrebroek, East Flanders, Belgium, Journal of Field Archaeology, 28(3/4), 253-69.

Darque-Ceretti, E., and Felder, E., 2003, Adhésion et adherence: sciences et techniques de l'ingénieur, 246-51, CNRS Editions, Paris.

Da Silva, L. F. M., and Adam, R. D., 2005, Measurement of the mechanical properties of structural adhesives in tension and shear over a wide range of temperatures, Journal of Adhesion Science and Technology, 19, 109-41.

Fischer, A., Vemming-Hansen, P., and Rasmussen, P., 1984, Macro and micro wear traces on lithic projectile points: experimental results and prehistoric examples, Journal of Danish Archaeology, 3, 19-46.

Gaillard, Y., Girard, M., Monge, G., Burr, A., Darque-Ceretti, E., and Felder, E., 2013, Superplastic behavior of rosin/beeswax blends at room temperature, Journal of Applied Polymer Science, 128(5), 2713-19.

Gaillard, Y., Mija, A., Burr, A., Darque-Ceretti, E., Felder, E., and Sbirrazzuoli, N., 2011, Green material composites from renewable resources: polymorphic transitions and phase diagram of beeswax/rosin resin, Thermochimica Acta, 521(1-2), 90-7.

Geneste, J.-M., and Plisson, H., 1986, Le Solutréen de la grotte de Combe Saunière 1 (Dordogne): première approche palethnologique, Gallia Préhistoire, 29, 9-27.

Geneste, J.-M., and Plisson, H., 1990, Technologie fonctionnelle des pointes à cran solutréennes: l'apport des nouvelles données de la grotte de Combe Saunière (Dordogne), in Les industries à pointes foliacées du Paléolithique supérieur européen, Krakòw 1989, 293-320, E.R.A.U.L. no. 42, Liège.

Grünberg, J. M., 2002, Middle Palaeolithic birch-bark pitch, Antiquity, 76, 15-16. 
Grünberg, J. M., Graetsch, H., Baumer, U., and Koller, J., 1999, Untersuchung der mittelpaläolithischen 'Hartzreste' von Königsaue, Ldkr. Aschersleben-Stassfurt, Jahresschrift für mitteldeutsche Vorgeschichte, 81, 7-38.

G'Sell, C., and Jonas, J., 1979, Determination of the plastic behaviour of solid polymers at constant true strain rate, Journal of Material Science, 14, 583-91.

Guilbert, R., 2001, Gestion des industries lithiques mésolithiques du sud-est de la France, Thèse de l'Université de Paris I Panthéon-Sorbonne.

Iovita, R., Schönekeß, H., Gaudzinski-Windheuser, S., and Jäger, F., 2014, Projectile impact fractures and launching mechanisms: results of a controlled ballistic experiment using replica Levallois points, Journal of Archaeological Science, 48, 73-83.

Kameda, T., 2005, ${ }^{13} \mathrm{C}$ solid-state NMR analysis of heterogeneous structure of beeswax in native state, Journal of Physics D: Applied Physics, 38, 4313-20.

Kameda, T., and Tamada, Y., 2009, Variable-temperature ${ }^{13} \mathrm{C}$ solid-state NMR study of the molecular structure of honeybee wax and silk, International Journal of Biological Macromolecules, 44, 64-9.

Larsson, L., and Sjöström, A., 2011, Early Mesolithic flint-tipped arrows from Sweden, Antiquity, 85(330); available at http://antiquity.ac.uk/projgall/larsson330/ (accessed 1 March 2015).

Letourneux, C., and Pétillon, J.-M., 2008, Hunting lesions caused by osseous projectile points: experimental results and archaeological implications, Journal of Archaeological Science, 35, 2849-62.

Márquez, B., and Muñoz, J. F., 2008, Barbed and tanged arrowhead of extra-Cantabrian Solutrean: experimental programme, in Prehistoric technology 40 years later: functional studies and the Russian legacy. Proceedings of the international congress, Verona (Italy), 20-23 April 2005 (eds. L. Longo and N. N. Skakun), 379-82, British archaeological Reports, International Series, 1783, Archaeopress, Oxford.

Mazza, P. P. A., Martini, F., Sala, B., Magi, M., Colombini, M. P., Giachi, G., Landucci, F., Lemorini, C., Modugno, F., and Ribechini, E., 2006, A new Palaeolithic discovery: tar-hafted stone tools in a European Mid-Pleistocene bonebearing bed, Journal of Archaeological Science, 33, 1310-18.

Michel, S., 2011, Les premiers groupes mésolithiques de la France atlantique: enquête sur l'industrie lithique, Thèse de l'Université de Rennes 1.

Moss, E. H., and Newcomer, M. H., 1982, Reconstruction of tool use at Pincevent: microwear and experiments, in Tailler! Pourquoi faire: préhistoire et technologie lithique II (ed. D. Cahen), 289-312, Recent Progress in Microwear Studies. Studia Praehistorica Belgica 2, Koninklijk Museum voor Midden-Afrika, Tervuren.

Odell, G. H., and Cowan, F., 1986, Experiments with spears and arrows on animal targets, Journal of Field Archaeology, 13(2), 195-212.

O'Farrell, M., 2004, Les pointes de La Gravette de Corbiac (Dordogne) et considérations sur la chasse au Paléolithique supérieur ancient, in Approches fonctionnelles en préhistoire (eds. P. Bodu and C. Constantin), 121-38, Société Préhistorique Française, Paris.

Pargeter, J., 2007, Howieson Poort segments as hunting weapons: experiments with replicated projectiles, The South African Archaeological Bulletin, 62(186), 147-53.

Pétillon, J.-M., Bignon, O., Bodu, P., Cattelain, P., Debout, G., Langlais, M., Laroulandie, V., Plisson, H., and Valentin, B., 2011, Hard core and cutting edge: experimental manufacture and use of Magdalenian composite projectile tips, Journal of Archaeological Science, 38(6), 1266-83.

Pokines, J. T., 1998, Experimental replication and use of Cantabrian Lower Magdalenian antler projectile points, Journal of Archaeological Science, 25, 875-86.

Regert, M., Alexandre, V., Thomas, N., and Lattuati-Derieux, A., 2006, Molecular characterisation of birch bark tar by headspace solid-phase microextraction gas chromatography - mass spectrometry: a new way for identifying archaeological glues, Journal of Chromatography A, 1101, 245-53.

Regert, M., Colinart, S., Degrand, L., and Decavallas, O., 2001, Chemical alteration and use of beeswax through time: accelerated ageing test and analysis of archaeological samples from various environmental contexts, Archaeometry, 43, 549-69.

Regert, M., Vacher, S., Moulherat, C., and Decavallas, O., 2003, Adhesive production and pottery function during the Iron Age at the site of Grand Aunay (Sarthe, France), Archaeometry, 45, 101-20.

Regert, M., Delacotte, J. M., Menu, M., Petrequin, P., and Rolando, C., 1998, Identification of Neolithic hafting adhesives from two lake dwellings at Chalain (Jura, France), Ancient Biomolecules, 2, 81-96.

Rots, V., and Plisson, H., 2014, Projectiles and the abuse of the use-wear method in search for impact, Journal of Archaeological Science, 48, 154-65.

Rozoy, J.-G., 1978, Les derniers chasseurs: l'epipaléolithique en France et en Belgique. Essai de synthèse, 3 vols, Bulletin de la Société Archéologique Champenoise (numéro spécial), Charleville.

Shea, J., Davis, Z., and Brown, K., 2001, Experimental tests of Middle Palaeolithic spear points using a calibrated crossbow, Journal of Archaeological Science, 28, 807-16. 
Sisk, M. L., and Shea, J. J., 2009, Experimental use and quantitative performance analysis of triangular flakes (Levallois points) used as arrowheads, Journal of Archaeological Science, 36, 2039-47.

Soriano, S., 1998, Les microgravettes du Périgordien de Rabier à Lanquais, Gallia Préhistoire, 40, 75-94.

Stodiek, U., 2000, Preliminary results of an experimental investigation of Magdalenian antler points, in La chasse dans la préhistoirelHunting in prehistory (eds. C. Bellier, P. Cattelain and M. Otte), 70-8, SRBAP (Anthropologie et Préhistoire, 111)—Université de Liège, Service de la Préhistoire (ERAUL, 51)—CERDARC (Artefacts, 8), Bruxelles.

Valentin, B., 2008, Jalons pour une paléohistoire des derniers chasseurs (XIVe-VI millénaire avant J.-C.), Publications de la Sorbonne, Cahiers archéologiques de Paris 1, 1, Paris.

Waguespack, N. M., Surovell, T. A., Denoyer, A., Dallow, A., Savage, A., Hyneman, J., and Tapster, D., 2009, Making a point: wood- versus stone-tipped projectiles, Antiquity, 83, 786-800.

Yaroshevich, A., Kaufman, D., Nuzhnyy, D., Bar-Yosef, O., and Weinstein-Evron, M., 2010, Design and performance of microlith implemented projectiles during the Middle and the Late Epipaleolithic of the Levant: experimental and archaeological evidence, Journal of Archaeological Science, 37, 368-88. 